\title{
海外のいわゆる「健康食品」に関する状況について
}

\author{
登田美 桜, ${ }^{*}$ 畧山智香子
}

\section{Current Problems Associated with Overseas Health Products}

\author{
Miou Toda* and Chikako Uneyama \\ Division of Food Safety Information, National Institute of Health Sciences; \\ 3-25-26 Tonomachi, Kawasaki-ku, Kawasaki 210-9501, Japan.
}

(Received July 12, 2018)

\begin{abstract}
In recent years, consumer interest in health and health foods (e.g., dietary supplements) has increased, and the types of and market for health foods have also expanded rapidly. The safety of health foods is a significant concern in many countries. Numerous adverse events associated with the consumption of health foods have been reported. There are cases that have resulted in serious liver failure, renal failure, and death in other countries. These products may contain undeclared medical ingredients and toxic chemical compounds that are illegally and intentionally added or contain natural plant toxins. Products containing high levels of heavy metals have also been reported to cause such adverse events. Some products remain on the market, even after regulatory agencies alert consumers and issue warnings to their sellers. Moreover, because people can buy health foods from sources overseas via the Internet, adverse effects associated with the use of such products remain a concern. Two cases of adverse events were reported in Japanese individuals who purchased "OxyElite Pro" products imported privately. They are advertised as weight-loss and muscle-building products and have been associated with many cases of liver failure and hepatitis in the USA. In this paper, regulatory systems and adverse events associated with the use of health foods in other countries are discussed.
\end{abstract}

Key words — health food; adverse event; regulatory system

\section{1. はじめに}

消費者の健康への関心の高まりを背景として, 健 康の維持・増進に役立つことを謳つた製品や，その ような効果を期待して摂取される多様な製品が「健 康食品」や「サプリメント」と呼ばれて流通してお り, 種類・販売量ともに増加し, 消費者の多くに利 用経験があると言われている。一方，市場拡大に 伴って製品の摂取による健康被害も報告されるよう になり, 健康食品の安全性確保が消費者の健康保護 を保証する上で重大な課題となっている.

本稿では，健康食品に関してより進んだ制度を持 つ European Union（EU）と米国の法的枠組みや定 義について概説するとともに，健康食品に関連して 報告された違反や健康被害の事例について述べる.

国立医薬品食品衛生研究所安全情報部（テ210-9501 川 崎市川崎区殿町 3-25-26)

*e-mail:miou@nihs.go.jp

本総説は, 日本薬学会第 138 年会シンポジウムS56 で

発表した内容を中心に記述したものである.

\section{2. 制度について}

日本では，経口的に損取され，医薬品に分類され るもの以外はすべて「食品」としての扱いとなる. 消費者が健康食品と呼んでいる製品も食品に分類さ れ, 法的に定義されているものとして保健機能食品 （特定保健用食品，栄養機能食品，機能性表示食品） がある．市場にはそれ以外にも健康食品と称する製 品やサプリメントと呼ばれ特定成分が濃縮された錠 剂やカプセル形態の製品が流通しているが，それら は法的に何の定義もなく一般食品として扱われ，有 効性・安全性ともに科学的根拠の確認は求められて いない.

日本で健康食品と呼ばれている製品と同様のもの が EU 及び米国の制度でどのように扱われているの か, 安全性の確保も含めて次に説明する.

2-1. EU のフードサプリメントＥU のフー ドサプリメント (food supplement) は, Directive 2002/46/EC の下，次のように定義され，食品に分 類される.

「通常の食事を補完し, 栄養素, 又は栄養学的・ 
Table 1. The Submission of Applications for the Authorization of Novel Foods Presented in EFSA Guidance ${ }^{1)}$

1: Administrative data

Applicant (company/organisation; contact person)

Regulatory status outside the European Union (under consideration, withdrawn, authorised or rejected)

2: Characterisation of the novel food, technical and scientific data

Identity of the novel food (e.g. chemical substances; polymers; microorganisms, fungi or algae; mineral origin; plants or their parts; animals or their parts; engineered nanomaterials)

Detailed description of the production process

Compositional data (qualitative and quantitative data, stability)

Specifications

History of use of the novel food and/or of its source (data on the use as food and non-food in countries outside of the EU, literature review and safety assessment)

Proposed uses and use levels and anticipated intake (e.g. target population, daily intake from food supplement and/or natural sources, esposure estimates for relevant undesirable substances)

Absorption, distribution, metabolism and excretion (ADME)

Nutritional information

Toxicological information (genotoxicity; subchronic toxicity; chronic toxicity and carcinogenicity; reproductive and developmental toxicity; human data)

Allergenicity

3: Annexes to the dossier

The glossary or abbreviations of terms

The certificates (on the accreditation of laboratories, certificates of analyses)

Full copies/reprints of all pertinent scientific data

Full study reports

Scientific opinions of national/international regulatory bodies

生理学的機能を有するその他の物質の濃縮物を単独 又は組み合わせて，次の形状で一定量を食する食 品：カプセル，トローチ，錠剤，丸剂及びその他の 類似形状，小袋入り粉末，液体アンプル，液体滴下 ボトル，並びに液体・粉末を少量単位で摂取できる ようにしたもの」

安全性については, 食品としての一般規則（衛生 管理，履歴管理等）の遵守はもちろんのこと，その 原料を規制することで確保しようとしている．原料 のうち，ビタミン・ミネラル類にはポジティブ制度 が取り入れられ，使用できるビタミン・ミネラル類 及びその化合物がリスト化されている．ほかにも植 物成分（抽出・濃縮物，等）や化学物質が使用され ることもあるが，Directive 2002/46/EC ではそれら への特別な規定はない。代わりに，「新規食品 (novel food)」に関する制度を導入している.

新規食品は, 1997 年 1 月 27 日, Regulation (EC) No 258/97 の下，規定された。これは EU 域 内で 1997 年 5 月 15 日より前に相当量の食経験がな い食品を新規食品とみなし，認可制度を導入して使
用を制限するというものである，新規食品の制度は 食品全般が対象ではあるが，使用目的がフードサプ リメントの原料とする例が非常に多い．従来から食 してきた食品でも，抽出や濃縮，形状の変更など加 工によりなんらかの化学的・物理的な変化が生じて いる場合には，そのものの食経験がないと見なさ れ，新規食品に該当する．現在は，改定後 2018 年 1 月 1 日に発効した Regulation (EU) No 2015/ 2283 が有効規則である。この改定は，食品分野で の技術向上による新しい食品の開発・利用拡大と手 続きの簡素化が目的であり, 新規食品の定義が細分 化され以前の規則に比べてより明確になった。

新規食品は，申請者から提出された資料を基に欧 州食品安全機関（European Food Safety Authority; EFSA）が安全性及び有効性を科学的に評価し，そ の結果に基づき欧州委員会（European Commission；EC）が認可の可否を決定する. EFSA は，科 学的評価を行うにあたり申請者が提出すべき情報/ データをまとめたガイダンス ${ }^{1-3)}$ を公表しており， その内容は非常に多岐にわたる (Table 1)，販売に 
あたり品質や安全性の評価が必要とされない食品分 野では特殊なケースである。ただし食品分野でも意 図的に使用する食品添加物と農薬・動物用医薬品に ついては認可制を導入しており, 品質と安全性につ いては医薬品の非臨床試験に近いレベルの情報が申 請時に必要となる，新規食品は，食経験のないもの を食品に使用するという点から見て食品添加物と類 似しており，その品質及び安全性についても食品添 加物の認可申請と同等レベルの立証が要求されてい る.

\section{2-2. 米国のダイエタリーサプリメント＼cjkstart米国} のダイエタリーサプリメント (dietary supplement; DS）は，食品に分類され，連邦食品医薬品化粧品 法 (Federal Food, Drug, and Cosmetic Act; FD\&C Act）を原則として，1994 年に制定されたダイエタ リーサプリメント健康教育法（Dietary Supplement Health and Education Act of 1994; DSHEA）が適用 される。 それら法律の中で DS は次の通り定義さ れ，錠侴，カプセル，ソフトジェル，液状及び粉末 などの製品がある.

「DS は食事の補完を目的とする製品で，次のダ イエタリー成分/原料（dietary ingredient; DI）を 1 つ以上含有するもの：(A) ビタミン，（B）ミネラ ル，(C) ハーブ又はその他の植物，(D) アミノ酸,

（E）総摂取量を増加させることで食事を補完する 目的でヒトが使用するダイエタリー物質，上記 (A)，(B)，(C)，(D)，(E) の濃縮物，代謝物，構成 成分，抽出物又はそれらの組合せ」

DSHEA によると，DS の製造業者と販売業者 は，食品として不良・不適である（adulterated）製 品，誤表示や消費者を誤解させるような不正表示を した製品を販売してはならない。したがって事業者 は，自らが販売しょうとしている製品の安全性と表 示が関連法規の要件を満たすことを販売前に確認す る必要がある. 販売にあたり U.S. Food and Drug Administration（FDA）による認可は必要ないが, 販売後 30 日以内に FDA への届出が必要である. 一方 FDA は，販売後に違法な製品への措置の責任 を負わなければならず，何か行政的な措置を行う場 合にはその根拠は FDA が準備しなければならない。

このような DSHEA の下 FDA は DS の安全性を 確保するため，1）食品の一般原則を適用する，

2）製造規範 (current good manufacturing practice;
cGMP）により製品の品質管理を行う，3）事業者 に重篤な健康被害の報告義務を課して実態の把握と 迅速な対応を可能にする，4）使用される成分を規 制する，というゃり方で管理している．FDA は DS に使用してよいものとして次を挙げている.

a） 食品に使われ既にフードサプライに存在して いる成分/原料を化学的変化なく使う.

b） 1994 年 10 月 15 日よりも前に DI としての使 用歴があるものを使う。

c） 1994 年 10 月 15 日よりも前に DI としての使 用歴がない新規食品成分/原料（new dietary ingredient; NDI）を使う.

d）一般的に安全と認められる（generally recognized as safe; GRAS）物質を使う。

これらのうち b）と c) は EU の新規食品の考え方 によく似ているが，FDA の場合は DS の成分/原料 としての使用に限定される。c)の NDI は，21 U.S.C. Sec. $350 b$ において, DSHEAが施行された 1994 年 10 月 15 日よりも前に米国内で DI として販 売されていなかった原料/成分と定義され，NDI を 含む製品は販売の 75 日前までに FDA への通知が 必要となる。もし通知なく販売された場合には adulterated と見なされ違反となる.

NDI の市販前通知の最終規則は 1997 年に施行さ れ，FDA が市販前通知に関する事業者向けガイダ

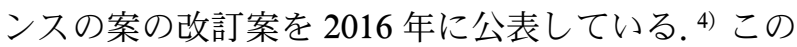
ガイダンスには，事業者が NDI の FDA 通知を行 うにあたり，どのようなデータや情報を検討し，提 出すべきなのかが Q\&A 形式で分かり易く記されて いる，その内容は，EUの新規食品の認可申請で提 出が求められている品質及び安全性に関するデー夕 及び情報（Table 1）とほぼ同じである。ただし， 有効性に関するデータ及び情報は必要ない。また安 全性試験の種類は，食品やDS を介した米国内外で の安全な食経験の状況に応じて必要性が異なる．た とえ安全な食経験があったとしても，NDI として 使用した場合に食経験よりも䎿取頻度・期間や用量 が多くなる場合，摂取経路が異なる場合，対象集団 が異なる場合などは，遺伝毒性，90 日間亜慢性毒 性，生殖・発達毒性， 1 年間慢性毒性又は 2 年間発 がん性，体内動態（ADME）試験の実施が状況に 応じて必要となる，過去に食経験が全くない場合が 最も厳しく, 一連の安全性試験の実施とデー夕提出 
が求められている。さらに NDI が使用された DS についても安全な製品であることを立証する必要が ある。

d)の GRAS 物質については, 1958 年の食品添加 物に関する法律の改定とともに定義された，GRAS として分類されるには，意図した使用の条件下にお いて，(1)科学的手段により安全であると認められる 場合，(2)1958 年 1 月 1 月より前の食品への一般的 な使用に基づく経験を通じて安全であると認められ る場合である。ただし，安全と認められるには食品 添加物の認可要件と同等の科学的根拠が求められる.

GRAS の手続きは，事業者が FDA に通知し FDA がそれを評価するという形式 (GRAS notification) をとっている．だが食品添加物に求められる販売前 の認可は必要ない.

\section{3. 健康食品の違反 ·健康被害について}

諸外国では，健康食品の摂取による健康被害や注 意喚起が絶えず報告されており，先に述べたように 安全性を確保するために制度をより厳しくする傾向 がみられる．特に米国では，2011 年に予防的な観 点で食品安全を強化することに主眼を置いた法律 (Food Safety Modernization Act; FSMA) が制定さ れ，現在はFDA の権限が以前よりも強くなり DS に関する措置も迅速かつ強化されている.

健康食品による被害は先進国やアジア諸国を中心 に報告されており，植物又はその成分が原因となり 健康被害が数十人規模で報告された主な事例を $\mathrm{Ta}$ ble 2 に示した。その症状は肝臓や腎臓，循環器な ぞ様々な臟器で生じていることがわかる.

これまで報告された健康被害では，主に次のよう な原因が指摘されている.

・有害な成分を含む植物の使用

-重金属（水銀，鉛，七素，等）の高濃度での含 有

・医薬品成分の含有

・有害な成分（化合物）の含有

・健康被害が報告された製品を再度販売

・病原性微生物による污染

・医薬品との相互作用

中でも特に悪質なのが，健康被害が多数報告され 当局から警告を受けたにもかかわらず，パッケージ や疑わしい成分を変更しただけで再度販売したこと が原因で被害がさらに拡大したという事例である.
Table 2. Adverse Effects Associated with the Use of Herbal Products

\begin{tabular}{l|l|l}
\hline \hline \multicolumn{1}{c|}{$\begin{array}{c}\text { Plant } \\
\text { (toxic components) }\end{array}$} & \multicolumn{1}{|c|}{ Uses } & \multicolumn{1}{c}{$\begin{array}{c}\text { Adverse } \\
\text { effects }\end{array}$} \\
\hline $\begin{array}{l}\text { Ephedra } \text { spp. } \\
\text { (ephedrine alkaloids) }\end{array}$ & $\begin{array}{l}\text { weight loss, athletic } \\
\text { performance }\end{array}$ & $\begin{array}{l}\text { circulatory } \\
\text { failure }\end{array}$ \\
\hline $\begin{array}{l}\text { Bitter orange } \\
\text { (synephrine) }\end{array}$ & weight loss & $\begin{array}{l}\text { circulatory } \\
\text { failure }\end{array}$ \\
\hline $\begin{array}{l}\text { Comfrey } \\
\text { (pyrrolizidine alkaloids) }\end{array}$ & health enhancement & liver failure \\
\hline Kava (kava lactones) & insomnia, anxiety relief & liver failure \\
\hline $\begin{array}{l}\text { Japanese star anise } \\
\text { (anisatin) }\end{array}$ & $\begin{array}{l}\text { (contamination in edi- } \\
\text { ble Chinese star anise) }\end{array}$ & $\begin{array}{l}\text { neurological } \\
\text { failure }\end{array}$ \\
\hline $\begin{array}{l}\text { Aristolochia } \text { spp. } \\
\text { (aristolochic acid) }\end{array}$ & $\begin{array}{l}\text { weight loss, Chinese } \\
\text { traditional medicines }\end{array}$ & $\begin{array}{l}\text { kidney } \\
\text { failure }\end{array}$ \\
\hline Black cohosh & monopause relief & liver failure \\
\hline $\begin{array}{l}\text { Bitter apricot kernels } \\
\text { (amygdalin) }\end{array}$ & anticancer & $\begin{array}{l}\text { cyanide } \\
\text { poisoning }\end{array}$ \\
\hline
\end{tabular}

例えば，2012 年 6 月， 8 月に FDA が警告した製 品「Reumofan Plus」と「Reumofan Plus Premium」 がある．関節炎，筋肉痛，骨粗鬆症及び骨がんのた めのナチュラル DS としてメキシコで製造された製 品が，全米及びインターネットで販売された。

FDA は，当該製品の摂取と関連する肝臟障害，出 血, 血糖悪化, 体重増加, 浮腫, 足のつり, 副腎機 能抑制，脳卒中，死亡を含む数十例の有害事象の報 告を受けており，検査で製品の表示に記載のなかつ たデキサメタゾン（副腎皮質ステロイド），ジクロ フェナックナトリウム（非ステロイド系抗炎症薬） 及びメトカルバモール（筋弛緩薬）が検出されたと して販売業者に警告している。しかし，一部の販売 業者が当該製品の名称とパッケージを変更して在庫 品を販売したため，同年 12 月に改めて FDA が警 告した。

ほかに，米国で警告対象になった製品を日本人が 個人輸入により摂取して健康被害を生じた例もある. 2011 年，米国 USPlabs 社が興奮作用や瘦身用の製 品として販売した製品「OxyElite Pro」を使用した 米国兵士 2 人の死亡が報告されたため当局が調査を

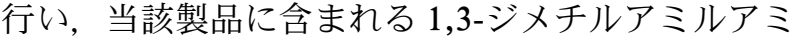
ン（1,3-dimethylamylamine; DMAA） と心臓発作 等の循環器障害との関連が指摘された。これを受け て米国，オーストラリア等の各国当局が当該製品に ついて警告し， USPlabs 社は 2012 年 7 月に DMAA を含む製品の販売を中止した。しかし，そ 
の後 DMAA の代わりに aegeline を使用して同じ商 品名とパッケージで製品を販売しており，今度は翌 年にハワイ州を中心に数十例の肝臓障害が報告5)さ れ，改めて米国等で警告が出された。 Aegeline はア ジアの bael の木 (Agele marmelos) の葉から抽出 されるアルカロイドである. DMAA と aegeline の 両成分とも NDI であるにもかかわらず， USPlabs 社は使用前に FDA 通知を行っていなかった。肝臓 障害の原因が aegeline なのかは確認がとれていない.

日本国内では，「OxyElite Pro」に関する米国の 警告を受けて 2013 年 10 月 9 日に厚生労働省の担当 部課から注意喚起の事務連絡6)が発出された。しか し，同年 12 月に「OxyElite Pro」を個人輸入して 1 力月間使用した 20 代女性の急性肝炎の事例7)が, 翌 2014 年 1 月には同じく個人輸入で使用した 30 代 女性の食欲不振，吐き気，嘔吐，黄㾝の事(例8) が報 告された。残念なのは, 先の事例では注意喚起が出 された後に製品の摂取を開始しており，個人レベル まで注意喚起を届けることが難しく, 海外で販売さ れた製品でも個人輸入で簡単に入手でき被害が拡大 する可能性があること，しかも個人輸入は実態を把 握し難いといつた問題点を改めて認識させられた.

また直近の事例として，FDA が何度も警告を発 しているクラトム (Kratom) を紹介する. クラト ムは，タイ，マレーシア，インドネシア等に自生す る植物 Mitragyna speciosa の通称で，オピオイド作 用を有する mitragynine などの成分を含む．日本で はクラトムに含まれる mitragynine や 7-hydroxymitragynine が指定薬物であるため販売は禁止され ている．米国ではオピオイド鎮痛薬の濫用や依存症 が国家的な問題になっており，それを背景にDS の クラトム製品はその代用品として，あるいはオピオ イド依存症・離脱症状やその他の症状の緩和，娛楽 を目的に販売されてきた。しかし死亡例も含む製品 の使用に関連した有害事例が多数報告され，FDA は徹底してクラトム製品の販売と使用の中止を呼び かけている. ${ }^{9,10)}$ さらにクラトム製品はサルモネラ 污染という別の問題でも警告とリコールが出され た. ${ }^{11)} \mathrm{DS} に よ る$ 健康被害は，製品に含まれる有害 な化学成分が原因として捉えられがちであるが，本 件のように微生物污染による健康被害が生じる可能 性もあるという教訓が示された事例であった。

\section{4. 最後に}

本シンポジウムでは，健康食品に係わる制度が進 んでいる欧米の現状と実際に発生している健康被害 について紹介した。欧米の制度は健康食品（サプリ メント）の安全性確保のために，予防的により厳し くする方向で順次改正されている. 国内においても 健康被害の発生を予防するためには，製品の安全性 を確保できる制度の導入，海外も含めて市場に流通 している健康食品やその原料や成分の把握，ぞのよ うな健康被害が生じているのかの把握が鍵になるで あろう。

利益相反＼cjkstart開示すべき利益相反はない.

\section{REFERENCES}

1) European Food Safety Authority (EFSA). "Guidance on the preparation and presentation of an application for authorisation of a novel food in the context of Regulation (EU) 2015/2283.": 〈https://www.efsa.europa.eu/ en/efsajournal/pub/4594〉, cited 21 June, 2018.

2) European Food Safety Authority (EFSA). "Guidance on the preparation and presentation of the notification and application for authorisation of traditional foods from third countries in the context of Regulation (EU) 2015/2283."': 〈https://www.efsa.europa.eu/ en/efsajournal/pub/4590 $\rangle$, cited 21 June, 2018.

3) European Food Safety Authority (EFSA). "Administrative guidance on the submission of applications for authorisation of a novel food pursuant to Article 10 of Regulation (EU) 2015/2283.": /http://www.efsa.europa. eu/en/supporting/pub/1381e $\rangle$, cited 21 June, 2018.

4) U.S. Food and Drug Administration (FDA). "Draft Guidance for Industry: Dietary Supplements: New Dietary Ingredient Notifications and Related Issues.": 〈http://www.fda. gov / Food / GuidanceRegulation / Guidance DocumentsRegulatoryInformation/ucm 257563 . htm $\rangle$, cited 21 June, 2018.

5) Chatham-Stephens K., Taylor E., Chang A., Peterson A., Daniel J., Martin C., Deuster P., 
Noe R., Kieszak S., Schier J., Klontz K., Lewis L., Drug Test. Anal., 9, 68-74 (2017).

6) Ministry of Health, Labour and Welfare (MHLW). "Safety Alert: OxyElite Pro. (9 October 2013)."': 〈http://www.mhlw.go.jp/ stf/houdou/0000025767.html $\rangle$, cited 21 June, 2018.

7) Ministry of Health, Labour and Welfare (MHLW). "Safety Alert (Second): OxyElite Pro. (25 December 2013).'”: 〈http://www. mhlw.go.jp / stf / houdou / 0000033542.html $\rangle$, cited 21 June, 2018.

8) Ministry of Health, Labour and Welfare (MHLW). "Press Release (10 January 2014).": 〈http://www.mhlw.go.jp/stf/houdou/00000 34391.html $>$, cited 21 June, 2018.

9) U.S. Food and Drug Administration (FDA). "Statement from FDA Commissioner Scott Gottlieb, M.D. on FDA advisory about deadly risks associated with kratom (14 November
2017).',:〈https://www.fda.gov/NewsEvents/ Newsroom/PressAnnouncements/ucm584970. htm $\rangle$, cited 21 June, 2018.

10) U.S. Food and Drug Administration (FDA). "Statement from FDA Commissioner Scott Gottlieb, M.D., on the agency's scientific evidence on the presence of opioid compounds in kratom, underscoring its potential for abuse (6 February 2018)."':〈https://www.fda.gov/ NewsEvents/Newsroom/PressAnnouncements/ ucm595622.htm 〉, cited 21 June, 2018.

11) U.S. Food and Drug Administration (FDA). "FDA Investigates Multistate Outbreak of Salmonella Infections Linked to Products Reported to Contain Kratom (15 March 2018)."': < http: / / s2027422842.t.en25.com / e / es?s = 2027422842\&e $=62483 \&$ elqTrackId $=$ B1F0B 909CCF90C71B9C490C37BFE6647\&elq $=726$ bfcafbfef4c07bb4b22ad24ecfd81\&elqaid $=2794$ \&elqat $=1\rangle$, cited 21 June, 2018. 